でょり以上に経済効率を上げるために，技街の向上を計 らなければならない。

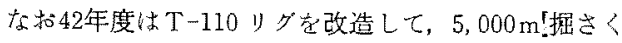
可能なりグとする計画で改造中である。

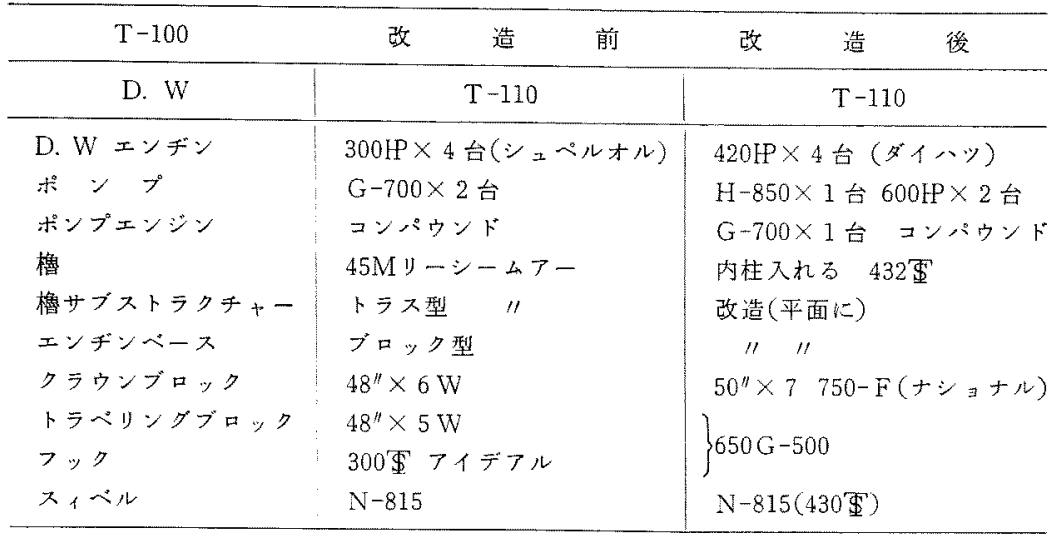

\title{
台湾の石油鉱 業*
}

\section{香積 賢 尚**}

\section{1. 油・カスス田の実状}

現在台湾で開発されている酒・ガス田は，日本時代か ら開発されている有名な錦水ガス田（苗栗の東北 $12 \mathrm{~km}$ ) て，8年前，日本時代に掘った 38 号井䘮 $3,583 \mathrm{~m}$ 加

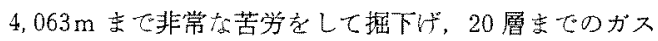
層を発見，17A拈上び18層を仕上げ，日産11万 $\mathrm{m}^{3}$ のガ スを生産したのが，復興の端緒となり，段々南部い上開 発され，最深井は $4.673 \mathrm{~m}$ で32層索で発見されている。 現均69，70号井を掘っていた。

5 年前に鉄砧山（苗栗の西南 $20 \mathrm{~km}$ ) に2,800mで錦水 013層に相当ずがス層を発見，既に13坑掘られ，6号 井は $5,100 \mathrm{~m}$ 掘っている。これは南北 $13 \mathrm{~km}$, 東西 $7 \mathrm{~km}$ の大ガス田を，現在採収しているI層たけけも日廒 300 万 $\mathrm{m}^{3}$ に達し，20〜30年続くとい加れている。

1 昨年, 日産 $180 \mathrm{k} l$ の油を宝山(新竹市の南 $15 \mathrm{~km}$ )に 発見, 現在 $4 ， 5$ 号井孛掘さく中てあるった。

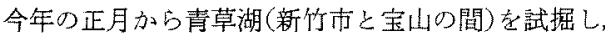
ガス層を発見，仕上げたとのことである。

古いものては戦前有名な出矿坑（苗菜の西南 $12 \mathrm{~km}$ ), 南部台湾飞竹頭崎・新営があるが，今は羔の面影をとど めているにすぎない。

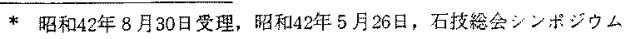
㝤演

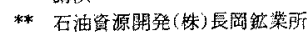

\section{2. 生 産 量}

$\begin{array}{ccl}\text { 生座井 } & \text { ガス } & \text { 生座量 } \\ 18 \text { 坑 } & 105 \text { 万 } \mathrm{m}^{3} / \mathrm{d} & 40 \mathrm{k} l / \mathrm{d} \\ 13 & 60 & 65 \\ 2 & 3 & 2 \\ 2 & 0.3 & \\ 3 & 0.2 & \end{array}$

能力は錦水・鉄砧山ともに大きいが，需要が伴なかね ため，閣鎖している坑井名克る。

\section{3. リク}

全部て10リグを所有しているが，主な毛のはてー110が

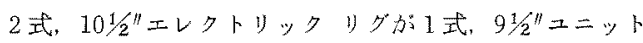

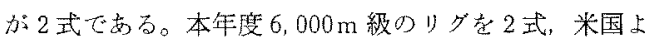
り購入する予定とのことで茄る。

\section{4. ケーシング プログラム}

日本とは全然違うケーシングプログラム走採用して 和り，非常に與味喍加心。

坑井深度や地質条件儿上って若干異なるが，3,000〜 $3,500 \mathrm{~m}, 4,000 \sim 4,500 \mathrm{~m}$ 称の坑井に大別吉ると，

(1) $3,000 \sim 3,500 \mathrm{~m}$ 級

$95 / 8^{\prime \prime} \times 7^{\prime \prime} \times 4,1 / 2 "$ 


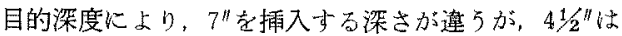
ライナーハンガーで7"の下部に七ットする。7゙を入れ ない場合の仕上鉄管け $51 / 2$ ”使用ずる。

(2) 4,000 4, 500 m 級

$133 / 8 " \times 95 / 8 " \times 7^{\prime \prime} \times 41 / 2 "$

インターメディエイトの深度は目的深度によって異な る。7"はライナーハソガーによって吊られ，41/2"がラ イナーハンガーにより7"下部に肙られた後、7゙はタイ バックされ吉。これは95\%の耐圧が低いためである。7゙, $4 \frac{1}{2}{ }^{\prime \prime C S G}$ はカップ付のものを使用している。

$\mathrm{CSG}$ の計算基準は
破裂に対して
1. 10 以上
引張に対して
1.75以上
王實に刘して
$0.65 \sim 0.85$ 以上

6,000m級の坑井を掘るために，既にケーシングプロ グラムが棓画されている。

\section{5 , 掘さく器具}

(1) ビット

ヒューズ・リード・セキュリティー・スミス拈よびシ カゴの 5 社和翰入しているが, 七ューズ・七キュリテ ィーの 2 社の評判はよいが、シカゴは悪かつた。ノッズ ルは小さなものを使用していた。

(2) ドリルパプ

$17 \frac{1}{2} " 12 \frac{1}{4} "$ 坑径には5"D”エキストラホール

81/2" 4 4/2n"E”扎よびX-951F

6" $31 / 2$ "E”特よび X-951F

$4 / 2$ "ライナ一内 $2 \% / 8$ スリムホール

(3) ドリルカラー

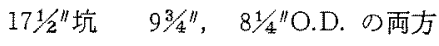

$12 \frac{1 / 4}{4} \quad 81 / 4 "$ O.D.

$81 / 2 "$ 63/4" O.D. (坑内状況の上小㭙) $61 / 4 " \mathrm{O}$.D.

6" $\quad 43^{\prime \prime}, \quad 4 \frac{1}{4} "$ O.D. の雨方

(4) スタビライザー

主にドリルコのブレード型を使用，組希合せは，ビッ ト+DC. $1+\mathrm{ST}+$ DC. $2+\mathrm{ST}+$ DC. $5 \sim 24$ 名普通使放九 て抬り、ペックドボールアセンブリーは抑留の恐れが あるのて使用していない。

(5) ケーシング プロテクター

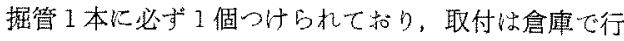
なわれ，現場では破損品のみ取皘ている。CSGの損篗 に恃特注意払っている。

(6) ケリーコック

ハイドリルのものをケリー上部に取付けている。

(3) B.O.P.
カメロンのF型を2段（掘管と盲）和よびハイドリル のGK型を上部に取付计ている。カメロンには必ず手で 名縍められるよらにホイールを取付故てる。

(8) アキュムレーター

坑井元より少なくと乎 $20 \mathrm{~m}$ ，遠いのは $50 \mathrm{~m}$ 離して拉 り，櫓下とアキュムレーター元で操作できる。

(9) チョークライン マニホールド

坑井敷地のはず机に設置され，ガスと泥水を分離し， ガスは遠くに放散し，泥水はシェーカータンクに落らる 上うにしている。チョークは固定式のものとアジャスタ ブルのタのと市る。

酎压は3,000 psi，5,000 psi，10,000 psiの3 種類あり， 後者は試ガス時に使用している。

(10) トングトルクダーギ

全リグに備付けて交り、ドリルカラー・掘管はもちろ ん，CSGの降下時に必ず使用している。

(11) デッチ

台湾の掘さくの特長しして，デッチはコの字型の連続 したジグザダにしてあることで，砂やシルト尔の沈砤に 役立てるととすに，温度冷却を計っている。

その他，ウエイトインディケーター・压力計あるが， 省略する。

\section{6. 掘さく泥水}

$81 / 2$ "坑に 7"CSG，\&た 6"坑に $4 \frac{1}{2}$ "CSG 䒠際に挿入 している事実を見て、かれわれはよくも2かえずに降が るものだと感心したが，彼等はをれは泥水が悪いからと 簡単に片付けるよ5な口振りであった。事実，掘さく泥 水についてはもらろ九輸入品を使用しているが，上く研 究して怙り，完全に使いこなして括り，何の不安り持っ ていないことが一見してかかっだ。

(1) CL-CLS 泥水

日本でい5ク口ム泥水で支るが，東新潟 NS-6 号井の 経娩から見ると耐温性が遥加吉り，安定している上う に思执れた。

(2) エマルジョン泥水

昨年より使用し始めた。特に前買の激しい地層に対し ては，今後この泥水で立间って行くとのことでこれは $\mathrm{CL}$ 泥水上りb遥かに調泥が楽だといっていた。作泥時 は高洒につくが，一旦作ったものは貯蔵ができるので， 次の坑井ではてれと混合する方法で作泥しているので， 幾分か節隇することがでる。

CL 泥水孝主に, エマルジョン泥水を良に使っている 名，深掘井が要求与る泥水のあり方に充分答えている上 5 に見受叮られるが，錦水53号井て $4,416 \mathrm{~m}, 320 \%(160$ C) で電検時72時間休えで何とるなく，栾九鉄砧山6 号 
井は $5.100 \mathrm{~m} ， 350^{\circ} \mathrm{F}(176.6 \mathrm{C})$ で問題はなかかったとい っている。菓新鼬 NS-6の涪をしたら，ンリッドコンテ ソトに䦗題があるのでないかと指摘された。

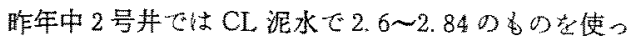
た。ハラライトでこの比重まで上げ，しか子流勤性は50足 では変加らず，XP-200㯪性がかかったとのことであ 30

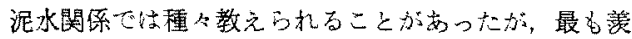
しく、恋た日本でかく古りたい上思ったのは，各坑开 の泥水を必とあらば每日で陚験室に運び, 試験をし， その結果で見場の泥水係に指示を与放て調泥させてい る。它の指示も县体的心行な㹝れ，全く現場としても試

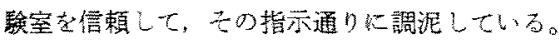

台湾に打ける掘さく泥水比重は $3,000 \mathrm{~m}$ 家て坑底圧十 最低 $300 \mathrm{psi}$ これ以㴗交+500 psi 以上としている。

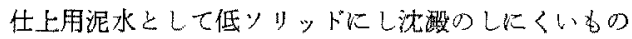
で，FCL 梳高温になると尔解し， $\mathrm{H}_{2} \mathrm{~S}$ を発生する。 $\mathrm{H}_{2} \mathrm{~S}$

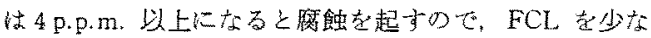
くXP-20 を主に調泥 L使用している。将来仕上用泥水 にェマルション诺水を使用したいといっていた。

現場の調泥器具として、デサンダー・デシルター战よ びクレイジェクターを使用しているが、深掘井以は今後 クレイジェクター住必ず備付け, 古いりリッドの除去に 努めるべ志と思5。

\section{7. セメンチンク}

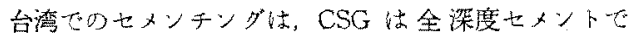

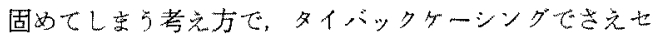
メンチングしている。

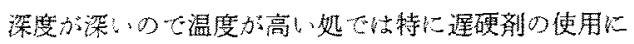

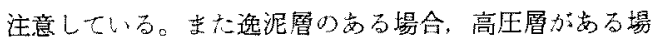

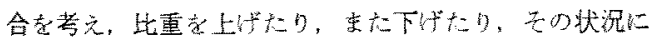
応じたせタント使用している。

(1) 七xント

台湾製のタラス“B”上米国上りクラス“E”索梌入して 使っている。前者は $4,000 \mathrm{n}$ 以浅に，後者な以深に使用 している

\section{(2) 選硬郕}

普通七メントわ時

$\mathrm{HR}-4$

ゲルセかント(ヘントナイト $6 \%$ 以下 $)$ HR-4

ダルセメント (8\%)下)

$\mathrm{HR}-7$

"E" $\mathrm{E}$ セメント

HR-12

(3) 女タント添秘剂

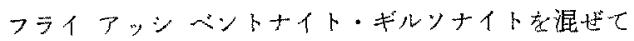

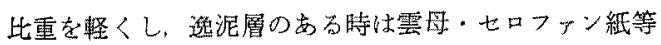
老入れている。
玨力の高い坑井には、、シイト・イルミナイト(チタ

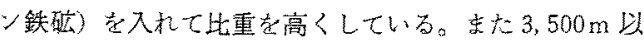

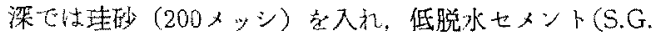
1.9〜2.0)考使用してい尚。

(4) 七xント試䲆

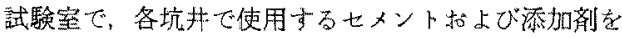

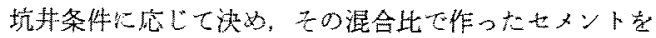
せメントコンシストメータ一て試験し，それて答が出た

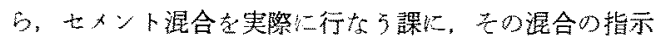

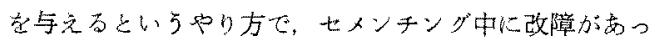

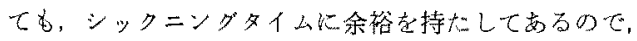

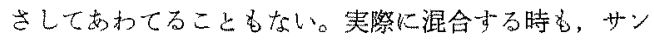

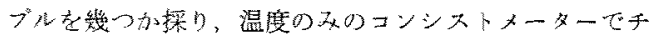
エックしている。

(5) せメンサング柿置

HT-400 2 台，T-10 4 台持っている。溶解ポン プには Tー10 t使用している。ポンプはすべて地上に置

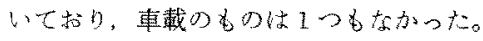

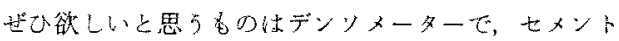

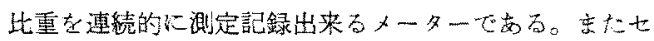
メント比重を一定にするため，サックドせメントを力ッ

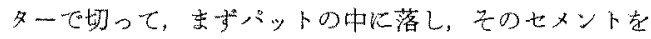
スクリューュンバでホッーーー落して，水上混合する

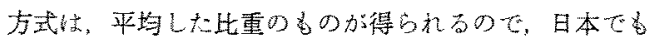
今後考无るべをやり方だ思 5 。

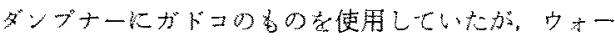
ターメンマリングは㤬とんどなかった。

(6) セxンチング作業

一度に3,000〜4,000八袋の七メント学使用子すが，七 メントコンテナーを持っていないので, 全部サックに詰

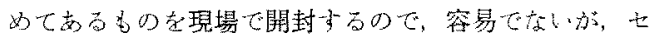
タンチングとなると日本と同じく，㫮セィントし真白に

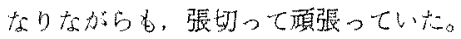

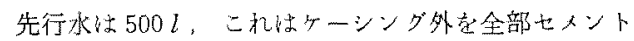

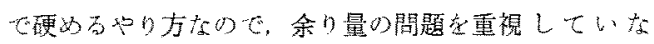

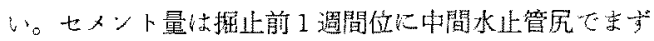
プラスチックの局壳掘管に入れて盾環し，それがマッド スタリーンに返ってくる時間と昍出量安測定し，坑底に

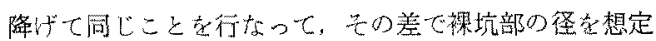

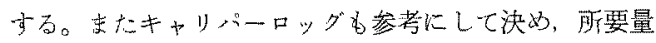

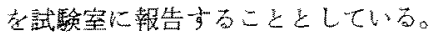

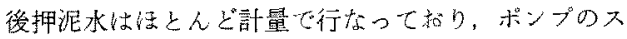

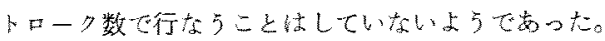

\section{8. 特殊作業扰よび器具}

(1) DST 
3,000 $\mathrm{m}$ 以上の裸孔ゆ DST 平然之行なって咕り， テスト络密閣20〜40分, 開放30〜60分, 密閣30〜40分飞 行なっている。CSG 内での DSTでは, 同じ要領て開放 恃 $4 \sim 8$ 時閐行なっている。

テスターはジンストンのCO型ハイドリックテス ター, B.T, 坑底圧测定器・ハックサーキュレーター等

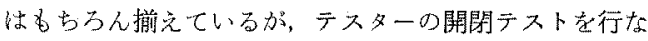
ら油圧装置も備之ている。テストの結果，ダメージレシ 才を計算し，生産能力の判定資料としている。

(2) 傾斜掘

鉄砧山9号井で行なったが，引まく行かず，日本の技 術を学びとるうと努力している。

器县も一応揃っているが，旧式なものが多い。

(3) フィッシングッールズ

オーバーショットはダラップルを1/32"刻㝊で各ドリル カラーO.D. に対し準備してあり，掘管のカッターもア ウトサイドカッタ一の欢用意していて，外加攻める年 のに重点を翼いて揃えている。

\section{9. 坑井仕上法}

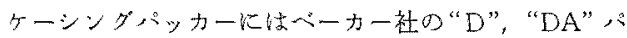
ッカーをシュランベルジャーサービスで行なっている。

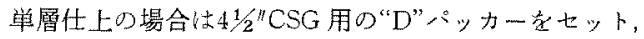
2 層同時仕上の場合嵝下層之上層の聞飞 $4 \%$ " CSG 用
“D”ハッカーを，上層の“DA”ハッカーは $4 \frac{1}{2}$ "ライナー ハンガーの上の 7"CSG にヒットする。チュービンダは ハイトリルの“CS”省使用，降下時に 1 本 1 本圧为試驗 をチュービンダテスターによって行ない, チュービング の漏洩に特に神経を使っている。坑四圧力7,000psi とい

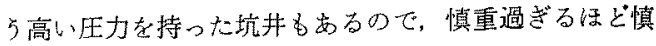
重で㸚る。

\section{0. 台湾の石油鉱業に対する感想}

(1) 泥水管理の体制がうまくでている。

(2) “N”グレード以上のケージング・チュービングに 対するる取报いが実に慎重である。

(3) 深い坑井に対与る経娩が多いせいか，澡さに齐し ての恐怖感支全然持っていない。

(4) $81 / 2^{\prime \prime}$ 坑に 7"CSG (カップリング O.D. $7 \frac{1}{2} 2^{\prime \prime}$ ) 6"坑

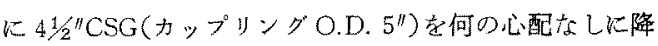
下している。参考炕もらったキャリパーロッグを見る

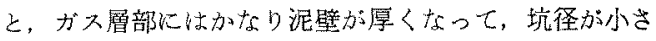
くなっているのに，CSGは降下きれている。

(5)全般的な見方として，井戸弆掘る基本的な考方方 忹，日本より優れている処が多々ある。特にA.P.I.儿対 する觔強がよく行な⿰れ, 自己流加少ないこと痛感し t心o

\section{国産油井用鋼管の強さと事故例についで}

\section{平岡 豊 助**}

昭和39年に藤川・萳阿潩油田が発見, 開発され, 深度 $2,300 \mathrm{~m}$ 層の仕上げに成功し，これが当時本邦最深の採 油井とされてきたが，昨年東新潟・松崎ガス田の発見に より，仕上げ深度は一举に2,900 $\mathrm{m}$ となり，さらに開発 の進展に伴ない㳭部ガス層の発見に上り深度 $3,200 \mathrm{~m}$ の ガス尿の仕上げb实施されてきている。この間，ケーシ ングについは全く事故がなく，安堵してい范次第であ る。チュービングについては，東新鼬地区に拈ける管体 の縦割れ，松崎地区に扮けるねじ漏れP105級チュービ ソク゚のアプセット部よりの切断等， 2，3解決しなければ ならない点がある。ドリルパイプについては、ツールシ ョイントの曻面磨耗が䦖題になっているが，わが社の主 に使用しているウェルドオンドリルパイプについては，

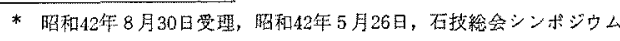
端湍

** 篣国不油(株)
硬装の强化につき対策克考究している。ウエルドオンド リルパイプは，使用開始後 3 年目に圧接面よりの切断事 故が相次いて発生したが，こ机は製作途上，王接時の加 熱不足と判明し，今日信頼性を取りもどしている。以 下，ケーシング・チェービング・ドリルバイプに分けて 話を進めたいと思う。

\section{1. ケーシンク}

現在，おが社で使用しているケーシングのサイズ・材 質・札し形式の別を第1表心示す。

次に深掘井に主として使用しているケーシングの性能 表を第 2 表に示守。

ケーシンククプログラムが定交れば，材筫とジョイント の强さとにより種ヶの規格のパイプを組㕕合せ，さらに は，その時点で最も低廉に，かつ坑井捔入時に製作，入 手の間に合う仕様のbのを選定し，購入しているので 